\title{
PRECEDENCE AS A CATEGORY OF A POLICODE TEXT OF POLITICAL CARTOONS IN THE ARABIC AND FRENCH LANGUAGES
}

\author{
Natalia M. Dugalich, Luisa N. Gishkaeva \\ Peoples' Friendship University of Russia (RUDN University) \\ 6, Miklukho-Maklaya Str., Moscow, Russia, 117198
}

\begin{abstract}
The article presents the material and the results of the study of a political cartoon in the Arabic and French languages. The relevance of this work is due to the description of the precedence in a polycode text in a comparative aspect due to the lack of a sufficient number of scientific papers affecting this issue.

The authors offer an overview of the main stages of the study of texts with iconic and verbal components and different types of the component links; and history of the appearance of the terms that nominate this type of text. The text in our research is characterized by the use of semiotic codes, for example, colour and kinesics; it is accompanied by paragraphemic means, which are font variations that go beyond the use of punctuation marks in the standard language, and topographic means, representing various flat layouts of text.

The implementation of the described type of text becomes a political discourse, the study of which also relates to the actual research topics of modern linguistics. It should be noted that a political cartoon is always a reflection of the opinion of society or an individual's reaction to a significant public event, and it is its universal feature, which makes it possible to compare the means and categories of a creolized text of political cartoon in different linguistic cultures/in different languages.

The object of the analysis is the creolized text of a political cartoon; the subject of the research is the category of precedence and its features aimed at the realization of the author's intention in the political cartoon in Arabic and French.

An important systemic characteristic of a creolized text is the category of precedence, which in this article corresponds to the category of intertextuality. The authors give examples to examine the use of precedent information at the level of the text and the image and their interconnection. The thorough analysis of the cartoons demonstrates the possibility of decoding a precedent sign in accordance with the type of speech culture of a native speaker.

Precedence in a political cartoon can be expressed by a textual or graphic representation of universal human precedent phenomena, civilizational precedent phenomena, onyms and events of a supraregional nature. The formal expression of precedence can also be a symbol. In the conclusion, the article proposes a summary of the results of the study.
\end{abstract}

Key words: policode text, political cartoon, the French language, the Arabic language

\section{INTRODUCTION}

The proposed research is devoted to the study of the precedence in the creolized text of political cartoons in Arabic and French.

A political cartoon is an universal instrument of dialogue between the government and the society, a reflection or reaction of the society to a certain political event, a series of events, or a person of national or world level. The goals and objectives of a political 
cartoon, the mechanism of its influence on the addressee, and its genre identity have a common tradition and basic components.

The interest in studying the connection between verbal and non-verbal components in language and the dynamic development of the media in the second half of the $20^{\text {th }}$ century led to the emergence of a significant number of linguistic works devoted to the study of a creolized text in general and in political discourse in particular. One of the important tasks facing the media is the formation of public opinion and coverage of political events both within a certain country and beyond its borders. Thus, radio, television, press and the Internet become platforms for active participants in the political debate. One of the most impressive ways to provide subjective information in the media is a creolized text of a political cartoon.

The special format of a creolized text as a combination of several semiotic codes for solving a common communicative task led to the use in the media discourse of units of two cognitive categories: intertextuality and precedence.

\section{CHARACTERISTICS OF CREOLIZED TEXT IN POLITICAL DISCOURSE}

The subject of the analysis of political discourse is a political text. The principle feature of the political text is its ideology and communication strategy, aimed at influence and persuasion.

According to M.A. Boyko [1], who generalized the data of special studies, despite the absence of a difference between the significance of verbal and iconic signs at the level of speech and signs, information is perceived by recipients differently: text message information is perceived and processed in a volume of less than $10 \%$, adding voice data increases this value to $40 \%$, and the accession of the iconic series gives a rise up to $55 \%$.

Visually received message "is faster and easier accepted as the truth, causes less fear" [2], "it seems more democratic" [3] and, as a rule, is perceived as some kind of objective information. However, the verbal component, the authorship of which is explicitly or potentially known, gives the message a subjective character. Thus, it is possible to draw a conclusion on the currently valid effect of the creolized text in political discourse at the present time.

The creolized text in political discourse is presented by the following genres: campaign leaflet, political poster, political cartoon, and images in the campaign text. Let us regard the main genre characteristics of a political cartoon - an image, usually containing a text component. The distinctive features of a political cartoon are the factual relevance, hyperbole, and satire in the representation of the iconic and verbal components.

The works devoted to the theoretical problems of political linguistics formulated a number of approaches to the study of creolized texts of political discourse:

- communicative direction (in which the focus of researchers' attention is on the analysis of communicative strategies and tactics in political discourse);

- rhetorical direction (in which the text and iconic components of the creolized text and their interaction are studied);

- semiotic direction (to which works of linguists, for example, on conceptual metaphor, belong). It was within the framework of semiotic research that the beginning 
of the study of creolized texts was laid. The image was considered as a special sign system, the role of graphic means in the semantic understanding of the text was studied separately. The most important works in this field are the works by L.V. Golovina (1986) [4], D.D. Zuev (1981) [5], Yu.A. Sorokin and E.F. Tarasov (1990) [6], L. Bardin (1975) [7], U. Kraft (1978) [8], M. Muckenhaupt (1986) [9], B. Spillner (1982) [10], and many others.

The following statements can be considered common provisions to a linguistic text (including a creolized text):

1) the pragmatic nature of the text is generally accepted in linguistics assertion;

2) text coherence implies consideration of the text as a combination of superphrasal elements that are connected by logical, semantic, grammatical, and stylistic characteristics;

3) the intentional nature of the text is associated with the realization of the author's intention and has a pronounced focus and subjectivity;

4) the situational nature of the text is the result of human cognitive activity in a particular situation;

5) the communicative nature of the text is associated with its communicative function as a means of transmitting the accumulated information. The text should correspond to the intentions of the addresser;

6) the intertextual nature of the text is almost always present in it.

The text as a product of human discursive activity reflects one of the "possible worlds", for "objectification of which the addressee uses various language means that activate certain features of the language" [11]. In modern language science, the description of linguistic phenomena is based on their assessment as contributing to the realization of the communicative function of the language [11. C. 519].

For the communicative point of view, we highlight the necessity of the analysis of language means in people's verbal behaviour and the evaluation of communicative tasks and attitudes [12-15, etc. $]$.

For cognitive analysis, it is important to put forward the role of language means in the processes of knowledge of the world and experience of society [16-21, etc.].

\section{THE STATUS OF THE CREOLIZED TEXT IN MODERN LINGUISTICS. STRUCTURE AND CONSISTENCY OF THE CREOLIZED TEXT}

In linguistic scientific discourse, the problem of describing and classifying creolized texts was first posed in works on semiotics and psycholinguistics as an attempt to define the role of non-verbal, and iconic (already in question) means in human cognitive activity [22 - 24]. One of the tasks of understanding these processes was to manage them through establishing the role of the combination and interaction of verbal and iconic information in the text, the other was the task of identifying discrete image units.

Another source of the theory of creolized texts was the attention of linguists to the typology of paralinguistic means of written communication, which, as a separate object of consideration, are described in the works by, for example, Yu.Ya. Gerchuk (1984) [25], S.F. Dobkin (1985) [26], A.A. Sidorov (1972) [27]. Following the works by G.O. Vinokur (1929) [28], A.A. Reformatsky (1933) [29], B.V. Tomashevsky (1930) 
[30], Yu.N. Tynyanov (1977) [31] on the verse chart, paralinguistic means of written communication were considered as the means that:

1) are associated with the grapheme system of the language;

2) accompany verbal speech;

3) serve to express additional connotations [32].

The concepts of the typology of paralinguistic means of written communication arose before the introduction of the question of nomination, status and peculiarities of the creolized text into the circle of linguistic problems. Thus, they became largely the basis of their investigation. After the emergence of the theory of the creolized text, the interest of linguists studying paralinguistic means of the language, for example, A.G. Baranov and P.B. Parshin [33], led to the appearance of a number of works where they clarified the classification division of paragraphemic writing tools of written communication for the following reasons:

_ "syngraphemic means"; these include all cases of artistic and stylistic (unmotivated from the point of view of punctuation) use of means on this level (i.e., units of the punctuation system);

— variation of fonts (in the classification of A.G. Baranov and P.B. Parshin "supragraphemic means");

_ "topographemic means", which include all possible planar variants of text placement [33].

In the works on the study of paragraphemic means there is a tendency of their wider definition, for example, the Dictionary on Pedagogical Speech Studies "by the degree of attachment to verbal signs highlights paralinguistic means that are directly adjacent and indirectly interacting with verbal signs" [34].

Assessing the significance of paralinguistic means in expressing the author's intention and in disclosing the meanings of a text, researchers build the following typology:

1) content carriers that do not need text accompanying (photos, drawings of various types);

2) paralinguistic means accompanying the text and adding semantic nuances or additional meanings for creating expression in the content of the text (e.g. fonts variation, marking, etc.);

3) paralinguistic means that form the perception of the text and do not make a change in the meaning (quality and format of the paper, etc.).

Thus, in this typology we are talking about paralinguistic active and paralinguistic passive texts [34]. The typology proposed by M.G. Shvetsova, classifies paralinguistic means as following:

1) connected with the verbal means of the text;

2) relevant to the organization of the content;

3) by function in the text [32].

The classification by N.N. Bol'shakova offers a description of the paralinguistic resources of the text from the standpoint of assessing the total volume of the creolized text and separates them according to "the degree of implication depth. The implication grows as the visual saturation of the paralinguistic element and the degree of explicitness of the author's intention hidden in it decreases. The illustrations have the smallest 
implicitness, then follow the architectonics of the text and topographemic means, under which the author sees planar variation of the text, supragraphemic means, i.e. font variation, and syngraphemic means (artistic and stylistic variation of punctuation marks)" [35].

The value of paralinguistic means in the text is variable, their participation is assessed as in the design of the text, i.e. plan of expression, they are not noticeable to the addressee and do not affect the substantive component of the text. Another part of paralinguistic means is significant, since their very participation in the text is a typeforming or genre-forming feature of these texts; they carry information that must be perceived in order to perform communication in full. In this case, we are talking about paralinguistically active texts, which include creolized texts.

The existing linguistic literature devoted to the study of the phenomenon of a creolized text contains a number of terms that denote one concept and which illustrate the history of the study of creolized texts.

Research devoted to the problem of describing and classifying creolized texts can be found in the works of such linguists as E.E. Anisimova (2003) [36], M.B. Voroshilova (2007) [37], L.V. Golovina (1986) [4], D.D. Zuev (1980) [5], Yu.A. Sorokin and E.F. Tarasov (1990) [6] and others.

Common to these concepts is the recognition of the existence of several types of information, two of which are verbal and iconic texts that are integrated and perceived by a person as a universal code. The decoding process does not separate the semantics of verbal and non-verbal signs; thus, creolized texts are recognized as complicated texts or higher order texts.

The term creolized text is found in the works by Yu.A. Sorokin and E.F. Tarasov, who used it in the following context: "texts the texture of which consists of two inhomogeneous parts (verbal language (speech) and non-verbal (belonging to other sign systems than a natural language)" [6. C. 181].

In the typology of texts by G.V. Eyger and V.L. Yukht, (1974) [38] the authors suggest the dichotomy of mono and polycode texts. "Polycode texts in a broad semiotic sense should also include cases of combining a natural language code with the code of another semiotic system (image, music, etc.)" [38. C. 107].

In modern linguistic literature, the terminological combination a polycode text still has a wide use, by which is meant, first of all, the text in which the message is encoded with semiotically heterogeneous means. A necessary condition for classifying a text as a polycode text is its paralinguistic active character, i.e. its paralinguistic means must be information carriers or introduce additional content into the content offered by the verbal component (see, for example, [39. C. 90]).

Exploring complicated texts, A.A. Bernatskaya uses the term iso-verbal complex [40]; A.V. Mikheev proposes the term izoverb [41].

Descriptively creolized texts were nominated as semiotically complicated texts [42]. However, in the work by O.V. Poymanova, it is proposed to call all combinations of visual "icons" and linguistic signs with the properties of a linked text as videoverbal texts [43]. 
As for the creolized text, researchers in the linguistic literature most often rely on the definition given by E.E. Anisimova, in which a creolized text is a text, "the body of which consists of two inhomogeneous parts: verbal (language/speech) and non-verbal (belonging to other, non-linguistic, semiotic systems)" [36. C. 8].

It is necessary to assess the connectedness of the components of a creolized text at the level of content (language content and compositional content) [36]. At the level of content, the connectivity of the verbal and iconic components can be traced on the example of semantic links between them, which can be of two main types: direct denotative correlation and mediated denotative correlation. The first type involves the designation of the same essence (objects of reality) by verbal and iconic signs. The second type considers the thematic or associative designation of different objects or situations by the signs of two systems of codes.

The choice of the type of correlation of the components in a creolized text is related to its genre originality; thus, the closest are the semantic links between iconic and verbal signs in the texts of complete creolization, which can be represented as:

1) a situation in which the verbal part matters, but is not independent in the semantic relation without correlation with the iconic part;

2) an example of a creolized text, in which the verbal component has a certain meaning, is independent, but can be correctly decoded only in relation to the image.

\section{INTERTEXTUALITY AND PRECEDENCE OF A CREOLIZED TEXT}

According to R. Barthes, "every text is an intertext; other texts are present at various levels in more or less recognizable forms... fragments of cultural codes, formulae, rhythmic structures, fragments of social idioms, etc. - all of them are absorbed by the text and mixed in it, since there is always a language before and around the text [44. C. 459].

A creolized text as a product of the development of mass communication and the expansion of mass culture often uses intertextual links.

Another cognitive category associated with the characteristics of a creolized text is the category of precedence.

The concept of precedence was proposed in the article by Yu.N. Karaulov "The role of precedent texts in the structure and functioning of a linguistic personality" and it has been expanded in other works. The precedent texts are understood as "significant for a particular personality in cognitive or emotional relations, having a suprapersonal character, i.e. well known to the wider environment of a given personality, including his or her predecessors and contemporaries, and, finally, those the appeal to whom is resumed repeatedly in the discourse of a given language personality" [45. C. 216]. In further development of the theory of precedence, the typical features of precedent texts are defined as:

1) well understood and known to all the speakers of a particular linguoculture;

2) informative and cognitively relevant;

3) frequently used in the speech of the speakers of this linguoculture.

The precedent names in advertising discourse, pragmatics and language of the media have vivid imagery, expressiveness, and typification. The use of a precedent phenomenon 
at various levels of precedence (name, statement, situation, text) is represented as connotative use, for example, of a proper name, realizing a metamorphic meaning and performing several functions: besides the nominative function, we can speak of the characterizing function, or, for example, assessment and typification.

However, in the linguistic works dedicated to the creolized text, two cognitive categories are often mixed - intertextuality and precedence. Differentiation of these concepts can be done through their connection with the time factor.

All mental components of the intertextuality category are temporarily filled, "intertextual signs are tested by time and tradition: they exist for several generations of people in the form of a certain cultural code, the existence of precedent phenomena is limited by the time of their reception and reinterpretation" [46. C. 3].

An intertextual sign during its life can be precedent, even several times, as part of the system of traditional material and spiritual values of an ethnos or civilization. The perception of the intertextual sign can occur in two different ways: textual and cognitive-personal. In the first case, the author seeks to formulate his thought and put it into the mind of the reader using such semantic elements that both sides of the communicative process operate. In the communicative-pragmatic bond author-text in a broad sense - reader, only the text is a constant value, because the cognitive base and the reader's system may change and there is a possibility of a lack of decoding of the author's intention.

Intertextuality as the ability of the text to accumulate information obtained from the surrounding reality and from other texts is described in such terms as the "semiotic memory of culture" (Yu.M. Lotman 1992) [36]; intertextuality makes the text a "diachronic matrix" (V.N. Toporov 1987) [36], and gives it the ability to have "extensibility for new revelations of thought" (A.N. Veselovsky quoted: Kuz'mina 2011) [46].

Intertextuality is a marker of aesthetic and epistemological validity of a text, if a new text does not have an intertextuality property, it does not have the opportunity to become a new link in the transition of a cultural code.

The possibility of decoding an intertextual sign is associated, among other conditions, with the type of speech culture of a native speaker. The carrier of the elite type of speech culture owns a fairly wide range of intellectual products of national culture and world civilization, i.e. he is aware of the main artifacts of material culture, literary masterpieces, the most significant works of art, etc. The carrier of an average level of speech culture as compared with the elite type has a narrowed intertextual thesaurus, which affects the possibility of decoding the intertextual message of the author.

The specifics of political discourse and media discourse, in contrast to the literary text, is associated more with precedence than with intertextuality. Nevertheless, it is possible to speak of several general variants of the cognitive mechanisms for processing an intertextual and precedent sign in a creolized text:

1) intertextual sign is a concise and recognizable embodiment of a social stereotype;

2) intertextual sign attracts the addressee with the recognizability of the form, under which there is no usual content, since for the purposes of manipulation it is replaced by new content; in this process, complex information is replaced by its simplest elements;

3 ) in the creolized text, such a form of intertextuality as interconicity is demanded, i.e. reference to the non-verbal prototext. 


\section{PRECEDENCE IN A POLITICAL CARTOON}

In modern linguistics, the theory of precedence has formed the following list of terms: precedent name (Gudkov 1999) [47], precedent statement (Krasnykh 2002) [48], precedent phenomenon (Gudkov, Krasnykh, Zakharenko et al. 1997) [49], precedent concept (Slyshkin 2000) [50] and many others. In the classification proposed below, we are based on the vision that any image or text that carries a reference to a well-known event is precedent. Based on the concept of G.G. Slyshkin [50], we highlight:

1) universal human precedent phenomena that form a kind of "universal cognitive space" for most people; their basis is a complex of literary, mythological, religious, fairytale sources, the heroes and subjects of which are perceived by the representatives of a certain culture in their original form, or interpreted as a well-known translation/ retelling [48. C. 51].

An example of this type of precedence in a creolized text of a political cartoon is the image of the genie (see Cartoon 1), in which background knowledge (submission, lamp as an attribute of power, fulfillment of any desires) describe the political roles of Egypt and Israel in foreign policy in the Middle Eastern region.

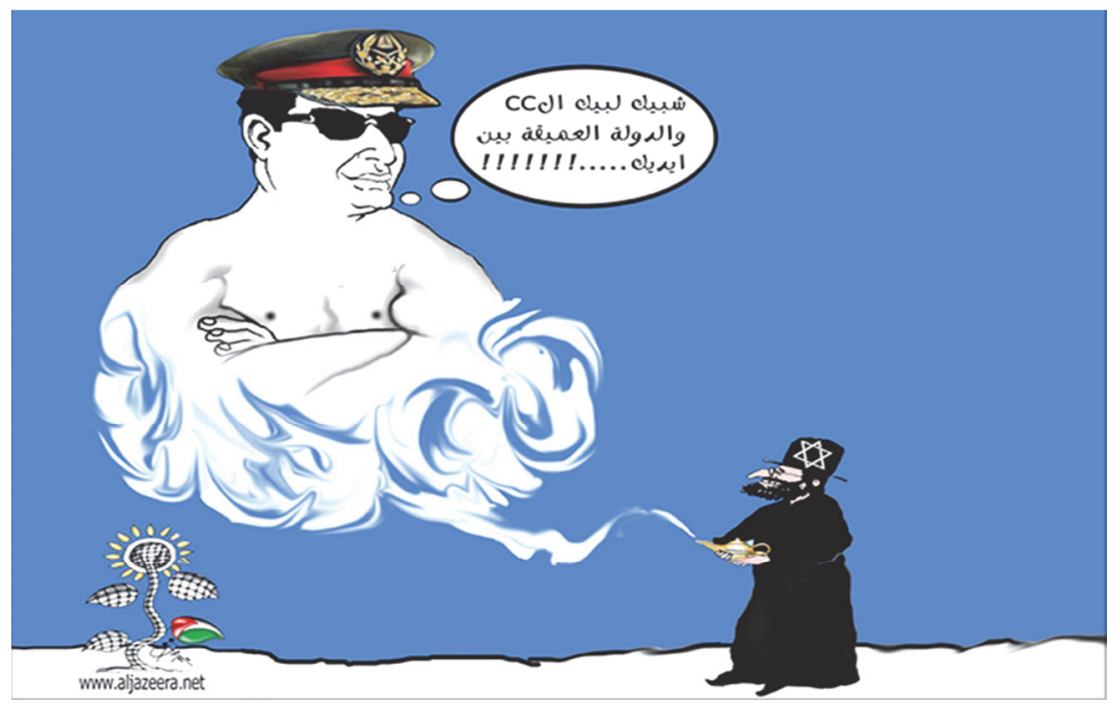

Cartoon 1

$$
\text { شبيك لبيك ال سي سي و الدولة العميقة بين ايديك }
$$

I obey you, Sisi is at your service, the Deep State is in your hands.

The presented cartoon reflects the author's view of the personality of Egyptian President Abdul-Fattah Khalil Al-Sisi and his policy. For the perception of the author's intention, it is necessary to consider the concept of the Deep State, a political term, which was originally used in the context of the political situation in Turkey (Derin devlet). 
We are talking about an alleged group of influential politicians in Turkey, highranking military men of a number of countries, intelligence services and the judicial system, and the mafia, for whom aspirations towards nationalism, corporatism and state interests were prioritized, but perceived by various political forces as anti-force. From different points of view, the concept of the Deep State can be narrowed to the antagonistic activity of individual groups to achieve their own interests and expanded to the type of state, which is based on the highest unrelated military levels, which allows to violate formal democratic institutions through informal ones.

Due to the intertextual component of this creolized text, the politician is perceived by the addressee as a slave who fulfills the wishes of the sovereign (here Israel). Thus, the author expresses his negative attitude to the figure of President Al-Sisi. In this case, an intertextual element is used, the content of which — submission - is understandable to each of the readers, regardless of their political literacy.

Other examples of common human precedent phenomena in the studied creolized texts of political cartoons are:

- The Trojan Horse (the image is of ancient Greek mythological origin and is expressed with an iconic sign);

- Ali Baba and the entrance to the treasure cave (the protagonist of an Arabian tale included in the collection "1001 nights"; the phenomenon is expressed verbally through the phrase فنح يا سعسم 'Open Sesame');

- Achilles heel (the image has a mythological origin and is expressed by an iconic sign);

- The Little Prince (the literary hero of the author's fairy tale by Antoine de SaintExupéry, the precedent phenomenon is expressed in a hybrid manner (the picture and the phrase S'il te plaît, dessine-moi ... 'Please draw me ...');

— La Fontaine's fable "Le Coq et le Renard", implicitly expressed by the dialogue of the rooster (President of France) and the fox (an employer) (this expression of the image can be considered hybrid, since the theme is supported by images (fox, rooster and chicken) and a text (garder les clefs du poulailler 'keep the key to the chicken coop');

2) civilizational precedent phenomena have a similar nature to common human precedent phenomena, but an important component of them is the value content that characterizes one of the stages of the development of a particular society.

An example of civilizational precedent phenomena is the image of Superman (see Cartoon 2) - icon of American culture; known since 1938. Superman is a superhero of comics, sponsored by Jerry Siegel and Joe Schuster, his main informative characteristics are inhuman abilities associated with extraterrestrial origin, and the desire to help everyone who is in trouble. The phenomenon is represented by a hybrid: the president of Egypt is depicted saving his country (t) in the guise of a girl and is dressed in a superman costume; in the text of the cartoon there is a nomination السبيسي مان 'Sisiman'. 


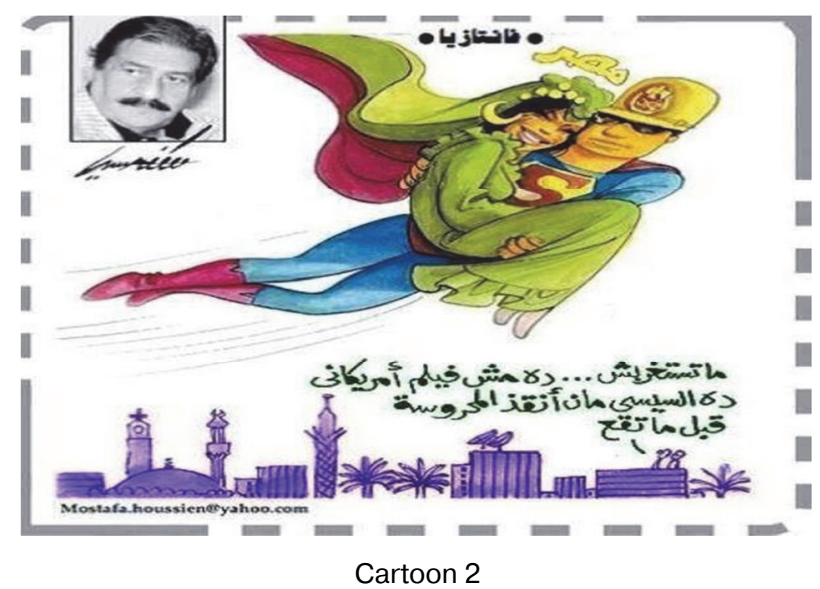

فانتازيا

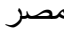

متستغربش...ده مش فيلم امريكاني ده السبسي مان انقذ المحروسة قبل ما تقع.

Fantasy

Egypt

Do not be surprised, this is not an American film, this is Sisiman saving Egypt from falling

The analyzed cartoon appeared immediately after Egyptian President Abdul-Fattah Khalil Al-Sisi came to power and was devoted to the political situation in Egypt. The author portrays the president as Superman, saving the country, depicted as a beautiful girl, from a fall/decline. This view of President Al-Sisi reflects the people's hope for a new leader, for his wise rule, which will allow Egypt not to "fall". In this cartoon we have analyzed, the civilizational precedent image of Superman and the national precedent image of Mahrusa (Egypt).

Other examples of civilizational precedent phenomenon can be:

_ eat biscuits' (transformed precedent phenomenon, an allusion to the famous phrase Qu'ils mangent de la brioche, which is known as: "If they have no bread, let them eat cake!". This replica is first mentioned in "Confessions" by JeanJacques Rousseau and traditionally refer to Marie-Antoinette, however, the connection with her is not confirmed by historical studies. This phrase means the lack of communication between the supreme power and the real problems of the people in the country;

- the image of Adolf Hitler (considered by us as a civilizational precedent phenomenon at the iconic level);

— the image of Muammar Gaddafi (supranational (Arabian) precedent phenomenon at the iconic level);

- an interesting precedent phenomenon, in our opinion, is the use of brand symbols in cartoons (meaning "non-native", "American", "global");

— GOULAG (the image is presented verbally and has the meaning "arrest for political views");

— values of the French democratic society (liberté, égalité, fraternité 'freedom, equality, fraternity'; the image is expressed verbally). 
We unite national and regional precedent phenomena, separated in the classification by G.G. Slyshkin [50], into one group due to the general supraregional nature of the content of a political cartoon. Their peculiarity lies in the fact that these precedent phenomena (onyms and events) are understandable to the average representative of a certain culture, in our case, an Arab speaking Arabic and a French-speaking European.

Here are some examples:

- a book abandoned by Francois Hollande (see Cartoon 3): a collection of fragments from an interview with the former president of France, prepared by Gérard Davet and Fabrice Lhomme, "Un président ne devrait pas dire ça!" (A president should not say that) on topical issues of French society and on world politics, in particular, the United States (came out on October 12, 2016, had a public response in France and the world);

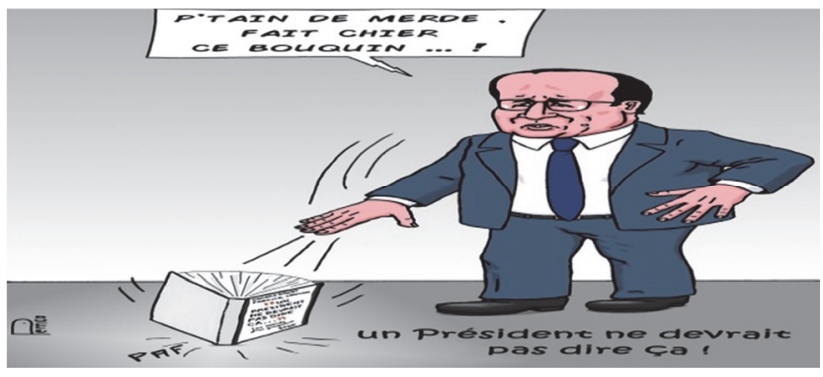

Cartoon 3

P'tain de merde. Fait chier ce bouquin...!

Un président ne devrait pas dire ça!

Damn it. Enrages this little book...!

A president should not say that!

- another example of a national and regional precedent phenomenon may be the lexical unit الفيـــephant' (a verbal allusion to Indians, who Arabs consider to be narrow-minded, stupid, and naive people).

\section{CONCLUSION}

This study allows us to draw the following conclusions:

1) The appeal to the genre presentation of political discourse and the comparative analysis of political caricature is a relevant question in linguistics due to the lack of a sufficient number of scientific research.

2) At a structural level, political cartoon is a creolized text, i.e. the combination of semiotic codes of the iconic and verbal levels, the compatibility of the components of which determines the originality of the cartoon. The analysis of a series of cartoons showed the use of semiotic codes such as colour at the level of the image and precedence at the level of the image and text.

3) Precedence can be expressed by textual or graphical representation of universal human precedent phenomena, civilizational precedent phenomena, onyms and events of a supraregional nature.

(с) Дугалич Н.М., Гишкаева Л.Н., 2019

Дата поступления: 01.03.2019

Дата приема в печать: 15.04.2019 


\section{REFERENCES}

1. Boyko, M.A. (2006). Functional analysis of the means of creating the image of the country (on the basis of German political creed texts) [abstract of dissertation]. Voronezh. (In Russ.).

2. Voitasek, L. (1981). Psychology of political propaganda. Moscow. (In Russ.).

3. Chudakova, N.M. (2005). Conceptual area "inanimate nature" as a source of metaphorical expansion in the discourse of Russian mass media (2000-2004) [dissertation]. Ekaterinburg. (In Russ.).

4. Golovina, L.V. (1986). Influence of iconic and verbal signs with a semantic perception of the text [abstract of dissertation]. Moscow. (In Russ.).

5. Zuev, D.D. (1981). The structure of the modern school textbook and the place in it of extratextual components (on the material of the analysis of textbooks of humanitarian disciplines) [abstract of dissertation]. Moscow. (In Russ.).

6. Sorokin, Yu.A. \& Tarasov, E.F. (1990). Creolized texts and their communicative function. In Optimization of speech influence. Moscow. pp. 180-186. (In Russ.).

7. Bardin, L. (1975). Le Text et l'image, Communication et languages, 26, 98-112.

8. Kraft, U. (1978). Comics lesen. Untersuchungen zur Textualität von Comics. Stuttgart.

9. Muckenhaupt, M. (1986). Text und Bild. Grundfragen der Beschreibung von Text-Bild-Kommunikation aus sprachwissenschaftlicher Sicht. Tübingen.

10. Spillner, B. (1982). Stilanalyse semiotisch komplexer Texte $\cdot$ Zum Verhältnis von sprachlicher und bildlicher Information in Werbeanzeigen. pp. 91-109.

11. Kubryakova, E.S. (2004). Language and knowledge. On the way of getting knowledge of the language: parts of speech from the cognitive point of view. In The role of language in the knowledge of the world. Academy of Sciences. Moscow: Languages of Slavic Culture. (In Russ.).

12. Arutyunova, N.D. (1990). Metaphor and Discourse. In Theory of Metaphor. Moscow: Progress. pp. 5-32. (In Russ.).

13. Afanasyeva, A.P. (2006). Knowledge of the value-meaning sphere of the personality through the symbol. Moscow. (In Russ.).

14. Grishaeva, L.I. (1998). Realization / non-realization of valent properties of verbs as one of the mechanisms of verbalization of extralinguistic reality (on the material of Russian and German verbs of the anthroposphere). Voronezh, Voronezh. State University. (In Russ.).

15. Semochko, S.V. (2004). The concept "Faust" as a constant of German culture [dissertation]. Voronezh. (In Russ.).

16. Anderson, D.R. (2002). Cognitive psychologists. St. Petersburg: Peter. (In Russ.).

17. Babushkin, A.P. (1996). Types of concepts in the lexico-phraseological semantics of the language. Voronezh. (In Russ.).

18. Boriskina, O.O. \& Kretov, A.A. (2003). The theory of language categorization. National linguistic consciousness through the prism of the cryptoclass. Voronezh. (In Russ.).

19. Laenko, L.V. (2005). Perceptual attribute as an object of nomination (02.10.19 - theory of language): dissertation abstract of dissertation. Voronezh. (In Russ.).

20. Popova, Z.D. \& Sternin, I.A. (2002). Language and national picture of the world. Voronezh. (In Russ.).

21. Sternin, I.A. (2004). Cognitive interpretation in linguo-cognitive studies. Issues of Cognitive Linguistics, 1, 65-69. (In Russ.).

22. Barthes, R. (1964). Elements of Semiology. NY: Hill and Wang.

23. Kraft, U. (1978). Comics lesen. Untersuchungen zur Textualität von Comics. Stuttgart.

24. Spillner, B. (1982). Stilanalyse semiotisch komplexer Texte · Zum Verhältnis von sprachlicher und bildlicher Information in Werbeanzeigen. Kodikas, Code. Ars Semeiotica, 4(5), 1, 91-106.

25. Gerchuk, Yu.Ya. (1984). The artistic structure of the book. Moscow: Kniga. (In Russ.).

26. Dobkin, S.F. (1985). The design of the book: the editor and the author. Moscow: Kniga. (In Russ.). 
27. Sidorov, A.A. (1972). Book and life. Moscow: Kniga. (In Russ.).

28. Vinokur, G.O. (1929). Culture of language. Moscow: Federatcia. (In Russ.).

29. Reformatsky, A.A. (1930). Technical edition of the book. In Theory and methods of work. Moscow: Gizlegir. (In Russ.).

30. Tomashevsky, B.V. (1930). Theory of Literature. Poetics. Moscow. (In Russ.).

31. Tynyanov, Yu.N. (1977). Poetics. Literary history. Movie. M., Moscow. (In Russ.).

32. Shvetsova, M.G. (2006). Paralinguistic tools in text linguistics [Electronic resource]. In LingvoMaster [website]. URL: http://www.lingvomaster.ru/files/210.pdf (accessed: 03.11.2017).

33. Baranov, A.N. \& Parshin, P.B. (1986). Linguistic mechanisms for the variative interpretation of reality as a means of influencing consciousness. In The role of language in the media of communication. Moscow: INION. pp. 100-143. (In Russ.).

34. Pedagogical speech science (1998). In Dictionary reference, T.A. Ladyzhenskaya \& A.K. Mikhalskaya (Eds.). Moscow: Flinta, Science. (In Russ.).

35. Bol'shakova, N.N. (2007). Game poetics in literary tales of Michael Ende [dissertation]. Smolensk. (In Russ.).

36. Anisimova, E.E. (2003). Linguistics of the text and intercultural communication (on the basis of creolized texts). Moscow: Academia. (In Russ.).

37. Voroshilova, M.B. (2007). Creolized text: aspects of the study. In Political linguistics. Release (1) 21, A.P. Chudinov (Ed.). Ekaterinburg. pp. 75-80. (In Russ.).

38. Eyger, G.V. \& Yukht, V.L. (1974). To the construction of a typology of texts. In Text Linguistics: Proceedings of the scientific conference at MGPI them M. Toreza. Moscow. pp. 103-109. (In Russ.).

39. Chernyavskaya, V.E. (2009). Text linguistics: Poly-codedness, Intertextuality, Interdiscursivity. Moscow: Librokom. (In Russ.).

40. Bernatskaya, A.A. (1987). Signature as a type of text. In Problems of linguistic analysis of text and communication. Irkutsk. pp. 118-128. (In Russ.).

41. Mikheev, A.V. (1987). On some types of interaction between images and text. In Types of communication and the content aspect of the language. Moscow: USSR Academy of Sciences, Institute of Linguistics. pp. 191-199. (In Russ.).

42. Protchenko, A.V. (2006). Typological and functional-stylistic characteristics of the Englishspeaking guidebook [abstract of dissertation]. Samara. (In Russ.).

43. Poymanova, O.V. (1997). Semantic space of a video verbal text [dissertation]. Moscow. (In Russ.).

44. Bart, R. (1989). Selected Works. Semiotics. Poetics. Moscow. (In Russ.).

45. Karaulov, Yu.N. (1987). Russian language and language personality. Moscow. (In Russ.).

46. Kuz'mina, N.A. (2011). Intertextuality and precedence as the basic cognitive categories of media discourse, Electronic scientific journal "Mediascope", 1. URL: http://www.mediascope.ru/ node/755 (accessed: 03.11.2017). (In Russ.).

47. Gudkov, D.B. (1999). Case name and case law. Moscow: MGU Publishing House. (In Russ.).

48. Krasnykh, V.V. (2002). Ethnopsycholinguistics and cultural linguistics. Moscow: Gnosis. (In Russ.).

49. Gudkov, D.B., Krasnykh, V.V., Zakharenko, I.V. \& Bagaeva, D.V. (1997). Some features of the functioning of precedent statements, Vestnik MGU. Series 9. Philology, 4, 106118. (In Russ.).

50. Slyshkin, G.G. (2000). From text to symbol: linguocultural concepts of precedent texts in consciousness and discourse. Moscow: Academia. (In Russ.).

\section{Links to caricatures (accessed: 10.2016-12.2017)}

1. Cartoon 1

http://www.aljazeera.net/news/caricature/2014/8/7/كاريكاتير-مصر-السيبسي 
2. Cartoon 2

http://3.bp.blogspot.com/vIpjae6s59k/UtlI550KI/AAAAAAAAdQM/k_Sfc0AMxmw/ s1600/5.jpg

3. Cartoon 3

http://perrico.over-blog.com/tag/dessin $\% 20$ politique $\% 20 \% 20$ caricature $\% 20$-politique $\% 20$ $\% 20 \mathrm{des} \sin \% 20 \mathrm{~d} \% 27$ actualite/

\title{
ПРЕЦЕДЕНТНОСТЬ КАК КАТЕГОРИЯ КРЕОЛИЗОВАННОГО ТЕКСТА ПОЛИТИЧЕСКОЙ КАРИКАТУРЫ НА АРАБСКОМ И ФРАНЦУЗСКОМ ЯЗЫКАХ
}

\author{
Н.М. Дугалич, Л.Н. Гишкаева \\ Российский университет дружбы народов \\ Ул. Миклухо-Маклая, 6, Москва, Россия, 117198
}

В статье представлены материал и итоги исследования политической карикатуры на арабском и французском языках. Актуальность данной работы обусловлена описанием прецедентности креолизованного текста в сопоставительном аспекте в силу отсутствия достаточного количества научных трудов, затрагивающих данную проблематику.

Автор предлагает обзор основных этапов изучения текстов, имеющих иконический и вербальный ряды, варианты связи их компонентов, историю появления терминов, номинующих данный вид текстов, который характеризуется также использованием семиотических кодов, например, цвета и кинессики, а также сопровождением параграфемными средствами, под которыми понимается шрифтовое варьирование, выходящее за рамки принятой в языке нормы использования единиц системы пунктуации, и топографемные средства, репрезентующие разнообразные плоскостные варианты размещения текста.

Реализацией описываемого типа текста становится политический дискурс, исследование которого также относится к актуальным исследовательским темам современной лингвистики. Необходимо отметить, что политическая карикатура всегда является отражением мнения социума или реакцией индивида на знаковое общественного событие, и это становится ее универсальной чертой, что позволяет сопоставить средства и категории креолизованного текста политической карикатуры в разных лингвокультурах / на разных языках.

Объектом проведенного анализа становится креолизованный текст политической карикатуры, предметом исследования - категория прецедентности и ее особенности для реализации авторской интенции в политической карикатуре на французском и арабском языках.

Важной системной характеристикой креолизованного текста является категория прецедентности, которая в данной статье соотносится с категорией интертекстуальности. Автор на конкретных примерах рассматривает использование прецедентной информации на уровне текста и изображения и их связи. Приведенный поэтапный разбор карикатуры демонстрирует возможность декодирования прецедентного знака в числе прочих условий также в соответствии с типом речевой культуры носителя языка.

Прецедентность в карикатуре может быть выражена текстовой или графической репрезентацией общечеловеческих прецедентных феноменов, цивилизационных прецедентных феноменов, онимов и событий надрегионального характера. Формальным выражением прецедентности может быть также символ. В заключении делается обобщение итогов проведенного исследования, в котором приведены варианты реализации категории прецедентности в политической карикатуре.

Ключевые слова: креолизованный текст, политическая карикатура, арабский язык, французский язык 


\section{БИБЛИОГРАФИЧЕСКИЙ СПИСОК}

1. Бойко М.А. Функциональный анализ средств создания образа страны (на материале немецких политических креолизованных текстов) (10.02.04 - германские языки): автореф. дис. ... канд. филол. наук. Воронеж, 2006.

2. Войтасик Л. Психология политической пропаганды. М., 1981.

3. Чудакова Н.М. Концептуальная область «неживая природа» как источник метафорической экспансии в дискурсе российских средств массовой информации (2000-2004 гг.) (10.02.01 - русский язык): дис. ... канд. филол. наук. Екатеринбург, 2005.

4. Головина Л.В. Влияние иконических и вербальных знаков при смысловом восприятии текста: автореф. дис. ... канд. филол. наук. М., 1986.

5. Зуев Д.Д. Структура современного школьного учебника и место в ней внетекстовых компонентов (на материале анализа учебников гуманитарных дисциплин): автореф. дис. ... канд. филол. наук. М., 1981.

6. Сорокин Ю.А., Тарасов Е.Ф. Креолизованные тексты и их коммуникативная функция // Оптимизация речевого воздействия. М., 1990. С. 180-186.

7. Bardin L. Le Text et l'image // Communication et languages. 1975. No 26. P. 98-112.

8. Kraft U. Comics lesen. Untersuchungen zur Textualität von Comics. Stuttgart, 1978.

9. Muckenhaupt M. Text und Bild. Grundfragen der Beschreibung von Text-Bild-Kommunikation aus sprachwissenschaftlicher Sicht. Tübingen, 1986.

10. Spillner B. Stilanalyse semiotisch komplexer Texte Zum Verhältnis von sprachlicher und bildlicher Information in Werbeanzeigen. 1982. P. 91-109.

11. Кубрякова Е.С. Язык и знание. На пути получения знаний о языке: части речи с когнитивной точки зрения. Роль языка в познании мира. Рос. академия наук. М.: Языки славянской культуры, 2004.

12. Арутюнова Н.Д. Метафора и дискурс // Теория метафоры. М.: Прогресс, 1990. С. 5-32.

13. Афанасьева А.П. Познание ценностно-смысловой сферы личности посредством символа. М.: ИИЦ МГУТ, 2006.

14. Гришаева Л.И. Реализация/нереализация валентных свойств глаголов как один из механизмов вербализации внеязыковой действительности (на материале русских и немецких глаголов антропосферы). Воронеж: Воронеж. гос. университет, 1998.

15. Семочко С.В. Концепт «Фауст» как константа немецкой культуры (10.02.04 - германские языки): дис. .... канд. филол. наук. Воронеж, 2004.

16. Андерсон Д.Р. Когнитивная психология. СПб.: Питер, 2002.

17. Бабушкин А.П. Типы концептов в лексико-фразеологической семантике языка. Воронеж, 1996.

18. Борискина О.О., Кретов А.А. Теория языковой категоризации. Национальное языковое сознание сквозь призму криптокласса. Воронеж, 2003. $211 \mathrm{c.}$

19. Лаенко Л.В. Перцептивный признак как объект номинации (10.02.19. — теория языка): автореф. дис. ... д-ра филол. наук. Воронеж, 2005.

20. Попова 3.Д., Стернин И.А. Язык и национальная картина мира. Воронеж, 2002.

21. Стернин И.А. Когнитивная интерпретация в лингвокогнитивных исследованиях // Вопросы когнитивной лингвистики. № 1. 2004. С. 65-69.

22. Barthes R. Elements of Semiology. NY: Hill and Wang, 1964.

23. Kraft U. Comics lesen. Untersuchungen zur Textualität von Comics. Stuttgart, 1978.

24. Spillner B. Stilanalyse semiotisch komplexer Texte Zum Verhältnis von sprachlicher und bildlicher Information in Werbeanzeigen // Kodikas, Code. Ars Semeiotica. 1982. no 4 (5). 1. C. $91-106$.

25. Герчук Ю.Я. Художественная структура книги. М.: Книга, 1984.

26. Добкин С.Ф. Оформление книги: редактору и автору. М.: Книга, 1985.

27. Сидоров А.А. Книга и жизнь. М.: Книга, 1972. 
28. Винокур Г.О. Культура языка. М.: Федерация, 1929.

29. Реформатский A.A. Техническая редакция книги. Теория и методика работы. М.: Гизлегиром, 1933.

30. Томашевский Б.В. Теория литературы. Поэтика. М., 1930.

31. Тынянов Ю.Н. Поэтика. История литературы. Кино. М., 1977.

32. Швецова М.Г. Паралингвистические средства в лингвистике текста // LingvoMaster: [сайт]. M., 2006. URL: http://www.lingvomaster.ru/files/210.pdf (дата обращения: 03.11.2017).

33. Баранов А.Н., Паршин П.Б. Языковые механизмы вариативной интерпретации действительности как средство воздействия на сознание // Роль языка в средствах массовой коммуникации. М.: ИНИОН, 1986. С. 100-143.

34. Педагогическое речеведение: словарь-справочник / под ред. Т.А. Ладыженской и А.К. Михальской. М.: Флинта, Наука, 1998.

35. Большакова Н.Н. Игровая поэтика в литературных сказках Михаэля Энде (10.02.04. германские языки): дис. ... канд. филол. наук. Смоленск, 2007.

36. Анисимова E.E. Лингвистика текста и межкультурная коммуникация (на материале креолизованных текстов). М.: Academia, 2003.

37. Ворошилова М.Б. Креолизованный текст: аспекты изучения // Политическая лингвистика. Вып. (1) 21 / Урал. гос. пед. ун-т; главный ред. А.П. Чудинов. Екатеринбург, 2007. C. $75-80$.

38. Ейгер Г.В., Юxт В.Л. К построению типологии текстов // Лингвистика текста: материалы научной конференции при МГПИИЯ им. М. Тореза. Ч. І. М., 1974. С. 103-109.

39. Чернявская B.E. Лингвистика текста: Поликодовость, Интертекстуальность, Интердискурсивность. М.: Либроком, 2009.

40. Берначкая A.A. Подпись как тип текста // Проблемы лингвистического анализа текста и коммуникации. Иркутск, 1987. С. 118-128.

41. Михеев A.B. О некоторых типах взаимодействия изображения и текста // Типы коммуникации и содержательный аспект языка. М.: АН СССР, Ин-т языкознания, 1987. C. $191-199$.

42. Протченко A.B. Типологические и функционально-стилистические характеристики англоязычного путеводителя (10.02.04 — германские языки): автореф. дис. ... канд. филол. наук. Самара, 2006.

43. Пойманова О.В. Семантическое пространство видеовербального текста (10.02.19 - теория языка): дис. ... канд. филол. наук. М., 1997.

44. Барт Р. Избранные работы. Семиотика. Поэтика. М., 1989.

45. Караулов Ю.Н. Русский язык и языковая личность. М., 1987.

46. Кузьмина Н.А. Интертекстуальность и прецедентность как базовые когнитивные категории медиадискурса // Электронный научный журнал «Медиаскоп». 2011. № 1. Электронный журнал факультета журналистики МГУ им. M.B. Ломоносова. URL: http://www.mediascope.ru/node/755 (дата обращения: 03.11.2017).

47. Гудков Д.Б. Прецедентное имя и проблемы прецедентности. М.: Изд-во МГУ, 1999.

48. Красных В.В. Этнопсихолингвистика и лингвокультурология. Курс лекций. М.: Гнозис, 2002.

49. Гудков Д.Б., Красных В.В., Захаренко И.В., Багаева Д.В. Некоторые особенности функционирования прецедентных высказываний // Вестник МГУ. Серия 9. Филология. 1997. № 4. C. $106-118$.

50. Слышкин Г.Г. От текста к символу: лингвокультурные концепты прецедентных текстов в сознании и дискурсе. М.: Academia, 2000.

\section{For citation:}

Dugalich, N.M. \& Gishkaeva, L.N. (2019). Precedence as a category of a policode text of political cartoons in the arabic and french languages. RUDN Journal of Language Studies, Semiotics and Semantics, 10 (2), 418 - 434. doi: 10.22363/2313-2299-2019-10-2-418-434. 


\section{Для цитирования:}

Дугалич Н.М., Гишкаева Л.Н. Прецедентность как категория креолизованного текста политической карикатуры на арабском и французском языках // Вестник Российского университета дружбы народов. Серия: Теория языка. Семиотика. Семантика. Т. 10. № 2. С. 418 - 434. doi: 10.22363/2313-2299-2019-10-2-418-434.

\section{Information about the authors:}

Natalia M. Dugalich, PhD, Associate Professor of the Department of Foreign Languages, RUDN University; academic interests: pragmatics, discourse analysis, methods of teaching foreign languages, comparativelinguistics; e-mail: avsineeva-nm@rudn.ru

Luisa N. Gishkaeva, PhD, Associate Professor of the Department of Foreign Languages, RUDN University; academic interests: pragmatics, discourse analysis, methods of teaching foreign languages, comparativelinguistics; e-mail: gishkaeva-ln@rudn.ru

\section{Сведения об авторах:}

Дугалич Наталья Михайловна, кандидат филологических наук, доцент кафедры иностранных языков филологического факультета РУДН; научные интересы: прагматика, дискурсивный анализ, методика преподавания иностранных языков, сравнительно-сопоставительное языкознание; e-mail: avsineeva-nm@rudn.ru

Гишкаева Луиза Нахидовна, кандидат филологических наук, доцент кафедры иностранных языков филологического факультета РУДН; научные интересы: прагматика, дискурсивный анализ, методика преподавания иностранных языков, сравнительно-сопоставительное языкознание; e-mail: gishkaeva-ln@rudn.ru 